\title{
Measuring the enabling environment of civil society: a global capability index
}

\author{
Lorenzo Fioramonti* and Olga Kononykhina
}

\author{
L. Fioramonti (*) \\ Centre for the Study of Governance Innovation, Department of Political Sciences, University of \\ Pretoria, Pretoria, South Africa \\ e-mail: Lorenzo.fioramonti@gmail.com; Lorenzo.fioramonti@up.ac.za \\ O. Kononykhina \\ Hertie School of Governance, Berlin, Germany
}

\begin{abstract}
During the last two decades, there have been various attempts at measuring and assessing the health of civil society. Some have focused almost exclusively on 'counting' the nonprofit while others have assessed the strength of nongovernmental organizations. Yet, these sectors are just a small part of a much larger environment. Moreover, they are the result of Western conceptualizations of civil society, thus not very helpful to understand civic participation in non-Western settings. Taking stock of these fundamental issues, this article presents the conceptual framework and methodology of a new global index to measure the 'enabling environment' of civil society, rather than its forms and institutional contours. Given the inherent diversity of civil societies worldwide, which defies any attempt at developing predetermined definitions, understanding the conditions that support civic participation becomes the most important objective for those interested in promoting a strong civil society arena. The index was launched by CIVICUS in late 2013 with the name of Enabling Environment Index and covers 200 countries and territories, making it the most ambitious attempt ever made at measuring civil society worldwide.
\end{abstract}


Key words: civil society; measurement; assessment; comparative analysis; capabilities; enabling environment.

\section{Introduction}

Since the 1990s, there have been several attempts at measuring and assessing the health of civil society. In this effort, some have focused almost exclusively on 'counting' the nonprofit, assuming that the sheer number and resources (both financial and human) mobilized by voluntary organizations was the best (and possibly the most relevant) representation of the state of civil society throughout the world (Salamon and Anheier 1998; Salamon et al 2004). Others, by using public opinion surveys, have assessed civil society by analyzing the type and scale of membership in voluntary organizations (Howard 2003). For some, assessing civil society was part of a broader strategy to support nongovernmental organizations (NGOs) in new democracies (especially in the former Soviet Union and in Africa). For others it was an opportunity for civil society organizations (CSOs) to identify their own strengths and weaknesses (USAID 2012; Heinrich and Fioramonti 2007).

In the last decade of the previous century, there was a strong interest in civil society per se, as phenomena of mass participation had led to important changes in political and social life. The images of common citizens gathering at the check points in Berlin in November 1989 had reverberated around the globe, leaving a profound mark on the social imaginary of the 1990s. It seemed as if nothing, not even the totalitarian power of the Communist regimes, could resist the bottom-up pressure of civil society. This is why, after the fall of the Berlin 
Wall, civil society came to be seen as the 'magic bullet' and NGOs came to dominate the civil society space (Edwards and Hulme 1996; Carothers 1999).

More recently the public discourse and reflection on civil society have become more nuanced. There is a growing realization that there is a plurality of civil societies, with actors that may have different features and objectives, including contrasting internal dynamics (Heinrich and Fioramonti 2007; Edwards 2009). Moreover, there is a general agreement that voluntary organizations are just a small group within a much larger environment: as a consequence, they can no longer be treated as key proxies for the whole civil society universe. Moreover, concepts such as nonprofit and nongovernmental are largely influenced by Western values and cultural frameworks, which make them unlikely to 'travel' across continents, thus reducing the capacity of these categories to capture the diverse world of civil society in other contexts, from Africa to the Middle East and Asia (Allen 1997; Abdelrahman 2002). Civil society is increasingly regarded as a 'sphere' or 'arena' of participation (Heinrich and Fioramonti 2007; Fioramonti and Fiori 2010). This has rendered many conventional methodologies of simply surveying NGOs, the nonprofit and/or the voluntary sector rather obsolete, at least for those researchers interested in understanding how civic participation contributes to democracy and development in different cultural and political settings (Scholte 2000).

At the policy level, similar dynamics have taken place. Aid agencies and most Western donors have traditionally endorsed a very narrow approach to civil society aid (Carothers and Ottaway 2000). They have limited their programmes to supporting NGOs and nonprofit 
organizations, leaving out the manifold manifestations of civic activism, especially social movements, indigenous organizations and, of course, the numerous forms of individual (unorganized) activism. Yet, when it comes to promoting participation, these 'alternative' forms of civic action are likely to be much more powerful and decisive than the spate of NGOs and nonprofits funded by international aid. The wave of uprisings that has been spanning the Arab World since early 2011 (which is usually referred to as the Arab Spring) was a powerful reality check for analysts and policy makers alike, who could not fathom how such a strong civic reaction was possible in countries where NGOs and nonprofits had been traditionally weak (Allen 1997).

What is civil society? What organizations are the best representatives of civil society? What expressions of civil society are more likely to capture the genuine demands and expectations of the people? While two decades ago there was a virtual consensus on it, nowadays the cultural particularities of civil society have become predominant. It is because of these evident shortcomings that the current debate on aid effectiveness has moved away from an exclusive focus on 'organized civil society' to identify what political, economic and social factors make people more likely to participate in civil society. ${ }^{\mathrm{a}}$ It seems as if the idea of civil society as a diverse 'arena' of participation is gaining currency in the aid industry, which implies the identification of new benchmarks for donors and policy makers. Civil society is increasingly considered as a vital component of a healthy society, principally in so far as it provides avenues and channels for citizens to organize and make their voices heard. 
Taking stock of these fundamental changes, this article presents the conceptual framework and methodology of a new global index that we have developed to measure the 'enabling environment' of civil society. The index was launched by CIVICUS in late 2013 with the name of Enabling Environment Index (EEI). The index covers 200 countries and territories, which makes it the most ambitious attempt ever made at measuring civil society worldwide. The analysis is organized as follows. In the next section, we critically review the most important assessments of civil society carried out so far by academics, multilateral institutions, aid agencies and NGOs. Then we introduce the conceptual and methodological underpinnings of this new global capability index. In the final sections, we provide some general conclusions as to the relevance of the new index for scholarly research and policy work.

\section{Assessing civil society: the pros and cons of existing approaches}

Back in 2001, The Economist asked mischievously: civil society 'is universally talked about in tones that suggest it is a Great Good, but for some people it presents a problem: what on earth is it?' (Grimond 2001: 18). Those were the heydays of the civil society 'talk', when international donors, policy makers and academics were fascinated by the power of civil society to bring about democratic change and development (Edwards and Hulme 1999). The end of the Cold War with the mass protests of the late 1980s and early 1990s, as well as the collapse of apartheid and the snowballing of many coloured revolutions in Eastern Europe, gave the impression that civil society could succeed where conventional party politics had failed (Diamond 1994). 
Ever since, the term civil society has been treated as a 'flee market' concept, influenced by fads and characterized by vagueness. According to some analysts, the concept of civil society has been mainly used as an analytical "hatstand" (Van Rooy 1998: 6), whose content varies according to who speaks about it. For others, civil society is characterized by "chameleon-like qualities" (Edwards 2009: 3). The media, for example, often talks about civil society in a rather opportunistic and haphazard way, sometimes to describe people who advance grievances (the so-called protesters), nonprofit associations, civic associations, or even society at large. NGOs have also contributed to this confusion mainly by projecting an image of civil society as being confined to professionalized organizations, thereby excluding all other forms of social activism (from social movements to informal groups and social networks) that do not enjoy the same degree of formalization and 'civility' (Jordan and van Tujil 2006; Fioramonti 2007). In some countries, especially in North Africa and the Middle East, the term civil society has been used to identify a rather narrow set of organizations - mostly Western funded - and distinguish them from the more 'political' groups, which are often religiously inspired (Al-Sayyid 1993; Roy 2005).

In the history of political thought, we can identify several complementary (and, at times, opposing) ways in which civil society has been conceptualized (Seligman 1992; Cohen and Arato 1994; Keane 1988). In classical Greek political thought, the term civil society described the 'good' society, that is, the set of manners, rules and forms of participation that characterized the polis (the city state) vis-à-vis other forms of 'less civilized' political regimes. In Rome's republican tradition, civil society was the ensemble of active citizens, who participated in the day-to-day administration of the res publica (Edwards 2009). While 
during the late imperial phase and the Middle Ages, the concept of civil society was weakened by the fusion of political power and religious authority, thus leaving little space for citizens' autonomous action, in modern political philosophy, the idea of civil society resurfaced with the development of liberalism (Seligman 1992; Cohen and Arato 1994; Gellner 1996; Keane 1998). For instance, according to John Locke and Adam Ferguson, civil society was the expression of the modern proprietary class, which created spaces of autonomy and self-determination from the state (Locke 1955; Ferguson 1995). Similarly, Tocqueville treated civil society as the locus of self-organization, characterized by associations and networks providing a breeding ground for democratic values practices (Tocqueville 2000; Putnam 2000). Another tradition of thought associated with the thinking of Hegel and Marx saw civil society as the ensemble of organizations between the state and the family, which functioned as a vehicle of cultural permeation throughout society according to the order imposed by the state and the capitalist class (Hunt 1990; Wood 1990). Revising the Marxist perspective, Gramsci described civil society as the realm of hegemony, constructed around the notion of consent, as opposed to the realm of force that pertains to the domination exerted by the state (Gramsci 1971). For the German philosopher Jurgen Habermas, civil society should be seen as the locus of communicative action, the socalled 'public sphere', in which ideas and values are discussed through rational civic debate (Habermas 1984; Calhoun 2001).

There have been several 'incarnations' of civil society in academic and practitioner debate, including definitions of civil society as a 'value', 'collective noun', 'space', 'historical moment', 'anti-hegemony', and 'anti-state' (Van Rooy, 1998: 6). Predominant approaches 
have been characterized by neo-Tocquevillean elements of self-organization and broad liberal criteria of separation from the state (and its interference). Within this ambit, civil society can encompass "all the organizations and associations that exist outside of the state (including the political parties) and the market" (Carothers 1999: 19) or constitute "the realm of organized social life that is voluntary, self-generating, (largely) self-supporting, autonomous from the state, and bound by a legal order or set of shared rules" (Diamond 1994: 5). No surprise, therefore, that the main empirical assessments of civil society around the world (largely influenced by the US experience) have simply equated civil society with the nonprofit sector.

The Comparative Nonprofit Sector Project (CNP) managed by the Centre for Civil Society Studies at Johns Hopkins University represented the first effort at measuring and assessing civil society in a comparative fashion. Begun in 1991 to document the rise of the nonprofit in modern governance systems (as a third sector besides the state and the market), the project expanded from 13 countries to 45, covering all continents and involving numerous teams of local researchers. Based on this work, the CNP launched a Global Civil Society Index, which measured the structure and financing of the nonprofit sector in strictly quantitative financial terms (Salamon, Sokolowski, \& Associates, 2004). Although the CNP pioneered academic research in the field, it inevitably depicted civil society as a static phenomenon. By focusing on the nonprofit (which, by definition, is an economic category), the project simply collapsed the diversity and inherent dynamism of civil society. The CNP provided detailed accounts of the financial and human resources available to nonprofits but did not gauge any of their capacity to represent and process citizens' needs, grievances or 
voice. In order to identify more 'political' dynamics within civil society, the United States Agency for International Development (USAID) partnered with the International Centre for Not-for-profit Law (ICNL) to develop an index of civil society in 1997. They piloted it in Eastern Europe and Eurasia with a view to assisting international donors in the democratization of the former Soviet Union. As USAID was interested in promoting democratic development in this region, it focused on advocacy organizations rather than on the more generic nonprofit. Not accidentally the study itself took the name of 'NGO Sustainability Index.' Because of its primary interest in political advocacy, this index aimed at mapping the key challenges facing pro-democracy NGOs in countries that had completed or were still undergoing democratic transitions. It included dimensions such as legal environment, advocacy and public image, as well as organizational capacity and financial viability (in 1999 it also added service provision and sectoral infrastructure). Only later, with a view to projecting a more inclusive picture of civil society, the project changed its name to CSO Sustainability Index (USAID 2012). In 2009, the coverage was extended to a number of sub-Saharan African countries and, in 2012, also some nations from the Middle East and North were included. In a similar fashion, the Overseas Development Institute carried out a World Governance Assessment (WGA) between 1999 and 2007, which included experts' perceptions of the contribution of civil society organizations to governance processes in 16 countries (Hyden et al. 2004).

All these assessments, whether adopting a more economic understanding of civil society (as was the case with the CNP) or a more advocacy oriented one (as was the case with the NGO/CSO Sustainability Index and the WGA), inevitably limited their observation to 
organized forms of civic activism. Some researchers pointed out the limitations of assessments that focus on organizations, including: "inconsistent categories of types of organizations, which vary tremendously from study to study (thus ruling out meaningful comparisons across countries)", "haphazard data collection, based on very unclear sampling methods (thus resulting in dubious claim of representativeness)" and "the 'death rates' of organizations that quite often cease to exist (thus becoming fictitious artefacts in the lists of organizations)" (Howard 2005: 231; see also Heinrich 2005). Moreover, there is a fundamental (both conceptual and substantive) reason why such an approach is inadequate:

the focus on organizations misses the crucial role played by people, by ordinary citizens, who form the heart and soul of civil society. In other words, an NGO can set up a fax machine and a website, but without members, without a constituency, it has very little to do with civil society (Howard 2005: 231).

Yet, although alternative studies moved away (at least methodologically) from a direct survey of organizations, for instance by using public opinion surveys, they inevitably ended up confining their observation to organized forms of participation. In most cases, they relied on data about individual membership of NGOs, nonprofit organizations, recreational associations, trade unions, business associations and so on (Howard 2003).

The Civil Society Index (CSI) promoted by CIVICUS: World Alliance for Citizen Participation was designed to overcome the shortcomings of the organizational focus adopted by most civil society assessments (Heinrich 2005). By endorsing a spatial definition of civil society as an 'arena' populated by groups, individuals and organizations, 
rather than a collective noun describing certain types of organizations, the CSI aimed to shift the focus from the 'list' of NGOs or nonprofits to the space for collective action (Heinrich and Fioramonti 2007). The 'arena' approach allowed for a more flexible (and continuously evolving) understanding of who belongs to civil society and under what circumstances. The concept of an arena (or a sphere) highlights the fact that civil society's contours are not set in stone: to the contrary, they are fluctuating and adapt to changing contexts. While conventional understandings tend to be rather static (that is, who is in or out of civil society is decided once and for all based on the specific characteristics of each organization), the CSI approach allowed for a more dynamic analysis of civil society's internal differences and its continuous evolution. Whether a NGO, a social movement, a liberation group or even a business association, what defines an organization's participation in civil society is its function here and now, rather than its formal legal status or mission (Heinrich and Fioramonti 2007).

In practice, however, the CSI revealed several limitations, just like any attempt to encapsulate civil society into a definitional framework. It turned out almost impossible to condense the plurality and diversity of civil society expressions across all continents of the world. As NGOs were leading the research efforts, this inevitably resulted in a conceptual bias against 'other' forms of civic activism. In some countries, political parties were included in the assessments, while in others they were excluded. In a few cases, trade unions were left out. In others, social movements and other more 'political' forms of participation were given only a marginal weight (Heinrich and Fioramonti 2007). 
What this review of existing comparative assessments reveals is that civil society is a fuzzy concept, whose actual boundaries are hard to define and whose conceptual characters are probably impossible to nail down. Existing operationalizations have been questioned for being a) too narrow when limiting civil society to the nonprofit world, b) too Westernized when looking at NGOs or nonprofits as the voices of the people, c) incoherent when trying to deal with organizations that, by definition, sit at the intersection between the state, the market and the nonprofit, such as political parties, trade unions, business associations, cooperatives and the like (Lewis 2001; Fowler 2002). By forcing such a complex and multifaceted phenomenon into predefined conceptual categories, whatever operational definition one may come up with will not be different from trying to "nail a pudding to the wall" (Kocka 2006: 37).

This is not to deny the importance that these projects have had for some specific and sectoral objectives. Studying the nonprofit is undoubtedly useful for statistical purposes (as an effort, for instance, to beef up satellite accounts at the national level) and also to design taxation legislation. Analyzing the strengths and weaknesses of advocacy groups can inform the policies of international donors, especially in countries like the US, where exporting liberal democratic values is considered a key goal of foreign policy. Promoting a self-assessment by NGOs can undoubtedly help the sector reinforce its accountability, transparency and ultimately legitimacy (Jordan and van Tujil 2006). Moreover, spatial approaches to civil society have attempted to fill a critical gap in social and political research. By providing more fluid definitions than those adopted by organizational studies, they have opened up new possibilities to rethink civil society as an arena of participation, 
through which individuals and/or groups promote their interests, voice their grievances or simply build social capital (Heinrich and Fioramonti 2007). Whether animated by progressive or regressive values, liberal or conservative principles, lay or religiously inspired visions of society, this arena of participation is a fundamental component for any society to articulate its needs and demands (Scholte 2000).

If the existence of such an arena is therefore undisputed, then what becomes more interesting from an analytical point of view is not who is part of it and who is not (the essential question of organizational approaches). Rather the key question becomes: what conditions make individuals capable of participating in such an arena to fulfil their goals? This is also a relevant question from a policy point of view. What are the enabling conditions that make it possible for individuals and groups to unite in different forms and capacities (regardless of culture, religion, language and values)? The next section deals precisely with such a question and presents a data collection method for global comparative research.

\section{Measuring the 'enabling environment' of civil society: a capability approach}

The conceptualization of civil society as an arena helps understand its multiple characters, its inherent contradictions and contrasting values. It also emphasizes its internal dynamism, with individuals and movements that may very well compete for visibility and influence rather than simply cooperate, as generally assumed by studies centring on NGOs and/or the nonprofit. If one accepts that civil society is an open and multiform social phenomenon characterized by internal tensions, complexities and complementarities; and if one agrees 
that, in its various manifestations, a dynamic public sphere is important for democratic participation, then the focus shifts from what constitutes civil society (and how to measure it) to what are the conditions that strengthen this arena of participation. So, while traditional research has focused on measuring organizations to get a sense of how well civil society is doing, we believe that there is much to be gained from assessing the extent to which civil society (whatever form it may take) operates within a conducive and enabling environment.

There is undeniable complexity in defining what constitutes an enabling environment for civil society. One approach would be to equate civil society with society at large and argue that higher socio-economic development is the best indication of an enabling civil society (UNDP 2013). An opposite approach, informed by legalistic considerations, would consider civil society's environment as consisting merely of legal and regulatory frameworks (World Movement for Democracy and ICNL 2012). There is merit in both approaches. As civil society is the arena of participation, it evidently is affected by socioeconomic factors as well as political and legal dimensions.

In order to combine analytical clarity and operationability, with a view to striking a balance between comprehensiveness and relevance for policy action, we define civil society's enabling environment as

a set of conditions that impact on the capacity of citizens (whether individually or in an organized fashion) to participate and engage in the civil society arena in a sustained and voluntary manner. 
As such, this approach recognizes that the enabling environment includes not only legal, regulatory and policy frameworks but also specific political, economic and socio-cultural factors. Against the background of such a definition of 'enabling environment,' we believe that the widely used capability approach holds significant potential in the assessment of civil society's environment, just as it serves as an analytical tool to understand the human development of society as a whole (UNDP 2013). Initially conceived in the 1980s as an approach to welfare economics, the capability approach is a broad normative framework for the evaluation and assessment of individual wellbeing and social arrangements, the design of policies, and proposals about societal change (Sen 1999). It has now grown as a highly influential framework in human development studies, and has led to the creation of the Human Development Index (HDI), the Inequality-adjusted HDI and the Gender Inequality Index (GII), which are broadly used by international organizations such as the UN and its different agencies, as well as the Basic Capabilities Index, promoted by civil society networks such as Social Watch (Social Watch 2011).

In welfare economics, the capability approach emphasizes the underlying conditions that make individuals 'capable' of fulfilling their own goals (Sen 1999). Unlike conventional assessments based on utility maximization, the capability approach rethinks the concept of development by shifting the attention away from output-based dimensions such as income. Moreover, by focusing on the underlying conditions that make individuals capable of achieving their 'own' goals, this approach presents a non-prescriptive recipe for comparative assessments: it does not force the various dimensions of human action into predetermined cultural, economic or political categories. Various experiences have also 
demonstrated that this model can be used as a framework to develop and evaluate a wide range of activities, from welfare policies to social integration projects, poverty eradication, household dynamics, decentralization reforms and gender issues (Comim, Qizilbash and Alkire 2010).

As discussed above, most conventional research on civil society has focused on measuring the scale of the organizational sector. In so doing, it has looked at parameters such as the income generated, the financial and human resources employed and the funding received by civil society organizations. In many regards, this approach resembles the traditional way of measuring development in terms of gross domestic product (GDP) as it is fundamentally based on 'outputs'. By applying the capability lens to the assessment of civil society, the attention shifts from what civil society 'produces' to the underlying conditions that make individuals able to promote collective action. This way of reasoning is not prescriptive (e.g. collective action can take place with or without organizations and can assume many different forms) and suitable for a deeper assessment of the enabling conditions that allow for civic action.

The capability approach rests on the distinction between two fundamental concepts: functioning and capability. While functioning indicates the attainment of objectives that are critical to one's development (e.g. nourishment, shelter, etc.), the concept of capability emphasizes the freedom or opportunities to attain such objectives and combine them according to one's preferences (Sen 1999). A person or a group that decide to fast may enjoy the same level of functioning as a person or a group who are deprived of food, yet 
their capabilities are fundamentally different. While the former choose to deprive themselves of food (thus they have the freedom and capability to do so), the latter are forced by structural conditions or external pressure (thus their capability of pursuing the most preferred course of action is impaired). What is critical in connecting capabilities to functionings is a third element in the capability approach: agency, understood as the willingness to act to bring about change and pursue whatever goals or values a person regards as important (Sen 1999: 19). Within this framework, we can talk of 'opportunity freedom' to describe people's ability to achieve their goals and of 'process freedom' to indicate the process through which these goals are attained. While capability is more closely related to opportunity freedom, agency relates to personal and/or collective process freedoms (Comim, Qizilbash and Alkire 2010: 4).

To be able to participate in the civil society arena, individuals have to possess a number of capabilities. When these capabilities are either not present or significantly underprovided, then participation (should it take place at all) becomes a 'last resort' act of resistance, a form of ultimate survival. Just like the difference between fasting and starving, those who participate out of despair cannot be considered as having the same opportunity freedoms as those who participate in civil society out of their own free choice. A capability approach emphasizes civic participation as a fundamental ingredient of a healthy society, not as a form extreme resistance out of despair. While it is true that forms of mobilization can be prompted by extreme deprivation, long-term civic engagement is only possible with a certain degree of empowerment. This is also consistent with the classical literature on revolutions, which sees sustained popular mobilizations as outcomes of a 'rise and drop' in 
socio-economic development, perceptions of 'relative' rather than absolute deprivation and growing cognitive gaps between attainments and expectations (Davies 1962; Geschwender 1968). Moreover, at the policy level, it would make little sense to argue that harsh social and human conditions are good for civil society just because, from time to time, they elicit some type of bottom-up reaction. Thus, it is fair to argue that an enabling environment for regular and systematic civic participation can only be achieved when a certain set of factors/capabilities are present at least in some degree. Some of these factors/capabilities will refer to individual opportunity freedoms (e.g. education, access to information, etc.) while others will be more context-based, such as legal regulations, communication infrastructure and collective cultural traits.

As is always the case in quantitative comparative research, our choice of capabilities was determined, as much as possible, by a focus on what is measurable. Moreover, from a policy perspective, the emphasis should be placed on what is 'actionable', that is, what can be altered through individual or collective agency. There are many contextual factors that may have an impact on civil society's operating environment, but some of these do not avail themselves to change. For example, structural conditions that have to do with environmental factors, climate, geographical exposure (e.g. landlocked territories vs. maritime areas) cannot be altered by human agency. Some historical patterns cannot be reversed in the short to medium term. Although important from a cognitive point of view, it would be a distraction to include such factors into an assessment that aims to promote change. 
In composing a matrix of indicators, it is also necessary to strike a balance between comprehensiveness and accessibility. Long lists are not necessarily better: often they are too 'heavy' for users to digest and their complexity may become a disadvantage in stimulating policy dialogue and action. Given these considerations, and consistent with the above working definition of enabling environment, we have identified three main dimensions:

1. Socio-economic environment: it assesses individual as well as context factors such as education, equity, gender equality and - quite importantly in the age of digital participation - the infrastructure of communication technologies;

2. Socio-cultural environment: it examines cultural factors reinforcing the capacity of citizens to get involved in the civil society arena, such as inter-personal trust, trust in civil society groups, societal tolerance, inclination to join collective action and solidarity;

3. Governance environment: it includes fundamental individual and structural capabilities that provide the minimum preconditions for social and political engagement. These include the rule of law, policy dialogue, personal and associational rights and the regulatory frameworks for civic organizations.

Each dimension is subdivided into various indicators, which are in turn made up of a number of existing data sources (some of which are official statistics, while others are produced by reputable international data agencies). All data sources and indicators have been rescaled between 0 (lowest level of capability) and 1 (highest level of capability), 
following a conventional approach in comparative measurements across the world (see for instance the scale adopted by the HDI).

Although aggregated into a final 'score', the various dimensions are displayed separately (Table 1). Such a 'dashboard approach', which preserves the informational contribution of the various components of the analysis without collapsing them into one final measurement, is in line with recent trends in social and economic statistics (e.g. Stiglitz, Sen and Fitoussi 2009). The dashboard also allows researchers to investigate sub-sections of the index and the relationship between dimensions and indicators. Moreover, it helps identify critical areas requiring some type of intervention, thus providing useful and actionable information to a variety of users, from researchers to policy makers and international donors, which may have different interests in studying the enabling environment of civil society.

Table 1 - Example of dashboard

\begin{tabular}{|l|l|l|l|l|}
\hline Country & Overall score & $\begin{array}{l}\text { Socio-economic } \\
\text { environment }\end{array}$ & $\begin{array}{l}\text { Socio-cultural } \\
\text { environment }\end{array}$ & $\begin{array}{l}\text { Governance } \\
\text { environment }\end{array}$ \\
\hline Neverland & 0.50 & 0.64 & 0.47 & 0.43 \\
\hline \multirow{5}{*}{} & Education $(0.73)$ & Trust $(0.62)$ & $\begin{array}{l}\text { Civil society } \\
\text { infrastructure } \\
(0.53)\end{array}$ \\
\cline { 3 - 5 } & $\begin{array}{l}\text { Communication } \\
(0.52)\end{array}$ & Tolerance $(0.32)$ & Rule of law $(0.33)$ \\
\cline { 2 - 4 } & $\ldots$ & $\ldots$ & $\ldots$ \\
\hline
\end{tabular}

\section{Enabling Environment Index: operationalization, aggregation and standardization}

The global network CIVICUS: World Alliance for Citizen Participation has adopted our capability methodology and the first pilot version of the EEI was launched in late 2013. As 
this index aims at covering the largest possible number of countries while relying on existing datasets, a variety of data has been gathered across 53 data sources. When multiple data sources were available for each indicator, we averaged them into one single number. This gave us a final set of 17 indicators, which are then aggregated to construct the EEI's three dimensions (Figure 1).

Figure 1 - EEI dimensions

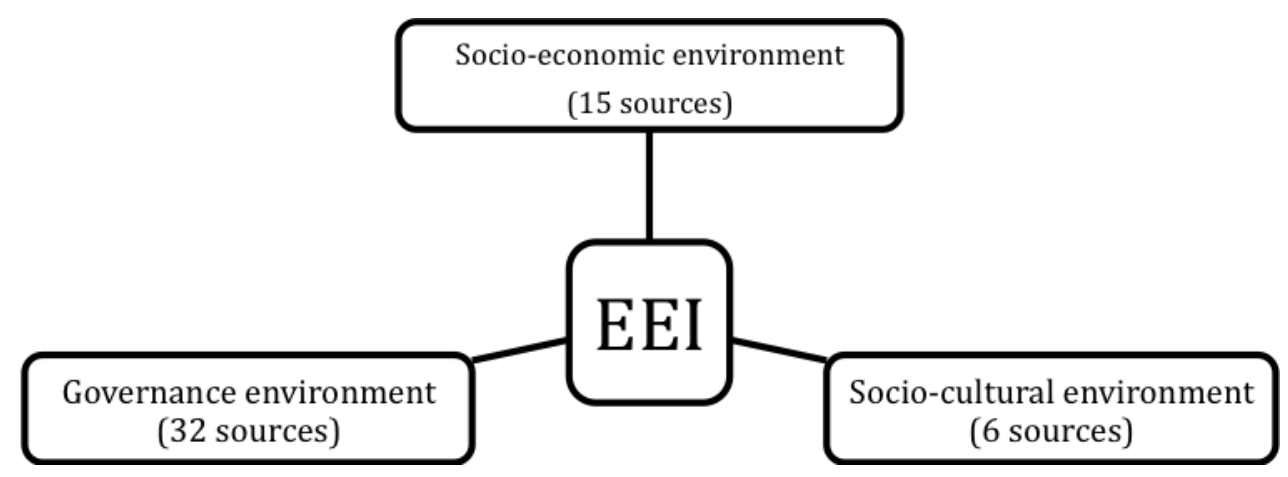

The dimension named 'socio-economic environment' includes 15 sources aggregated into four indicators: 1) education; 2) communication; 3) equity; 4) gender equality. The key data sources for the socio-economic dimension include the HDI and the Gender Inequality Index published in the Human Development Report, the World Bank's World Development Indicators, the Basic Capabilities Index and the Gender Equity Index published by Social Watch, the Gallup World View/Poll and a host of data from the International Telecommunication Unit, including percentages of people with access to the Internet and broadband users. It is important to note that we have intentionally excluded measurements of aggregate or per capita income from the socio-economic dimension, in line with the 
basic tenet of the capability approach, which focuses on opportunity freedoms rather than on output based utility, as well as a growing amount of research showing how GDP is not a good indicator of economic welfare and its inclusion in aggregate indexes would potentially distort the final results (Stiglitz, Sen and Fitoussi 2009; Jackson 2009; Fioramonti 2013). Table 2 reports the composition of the EEI's various dimensions.

Table 2 - EEI dimensions, indicators and data sources

\begin{tabular}{|r|r|}
\hline \multicolumn{1}{|l|}{ Socio-economic environment } & Governance environment \\
\hline Education (5 sources) & Civil society infrastructure (3 sources) \\
\hline Communication (5 sources) & Policy dialogue (2 sources) \\
\hline Equity (3 sources) & Corruption (2 sources) \\
\hline Gender equality (3 sources) & Political rights and freedoms (7 sources) \\
\hline Socio-cultural environment & Associational rights (2 sources) \\
\hline Propensity to participate (1 source) & Rule of law (5 sources) \\
\hline Tolerance (1 source) & Personal rights (5 sources) \\
\hline Trust (3 sources) & Legal context for organizations (1 source) \\
\hline Solidarity (2 sources) & Media freedoms (3 sources) \\
\hline
\end{tabular}

The 'socio-cultural environment' is made up of seven data sources organized along four indicators: 1) propensity to participate; 2) tolerance; 3) trust; 4) solidarity. Its data comes from the most recent waves of the World/European Values Surveys, the Eurobarometer, the Afrobarometer, the Latinobarometro, the Asian Barometer as well as the World Giving Index, which include useful information on interpersonal trust, tolerance, giving and the willingness of citizens to participate in various forms of collective action, from petitions to peaceful demonstrations. There is general agreement in the literature (e.g. Putnam 2000; Lin 2001) that a fundamental enabling factor in supporting collective action in the civil society sphere is social capital, defined as a set of interpersonal connections based on trust. 
Moreover, values such as tolerance, trust in civil society groups and solidarity are more likely to make individuals willing to join collective initiatives in the civil society arena.

Finally, the 'governance environment' is made up of 32 data sources organized into nine indicators: 1) civil society infrastructure; 2) policy dialogue; 3) corruption; 4) political rights and freedoms; 5) associational rights; 6) rule of law; 7) personal rights; 8) legal context for organizations; 9) media freedoms. For this final dimension, data is gathered from the USAID-sponsored CSO Sustainability Index, the Worldwide Governance Indicators, the Global Integrity Index, the Failed States Index developed by the Fund for Peace and Foreign Policy, the Democracy Index published by the Economist Intelligence Unit, Freedom House data and reports, Reporters Without Borders data on freedom of the press, the Bertelsmann Transformation Index, Transparency International's corruption data, the IBP Open Budget Survey, the Political Terror Scale developed by Amnesty International, the Trade Unions Rights Violations Survey and the Cingranelli-Richards Human Rights Dataset. We recognize that the governance environment could have included a much larger set of variables, as it speaks to the very core of rights and freedoms that ultimately make civic participation possible. Nevertheless, we focused on a more limited set of indicators with a view to stressing the importance of specific elements that have a direct bearing on the civic space.

The overall EEI score is the result of the final aggregation step, in which the three dimensions are weighted: both the socio-cultural and the socio-economic environments are given a weight of 0,25 out of 1 , while the governance environment is given a weight of 0,50 
because of the number of indicators it comprises (nine, as compared to only four for the other two dimensions) as well as the relative importance attributed to this dimension by civil society stakeholders consulted by CIVICUS. ${ }^{\mathrm{b}}$

As a result, the formula for the calculation of the EEI in a given country is:

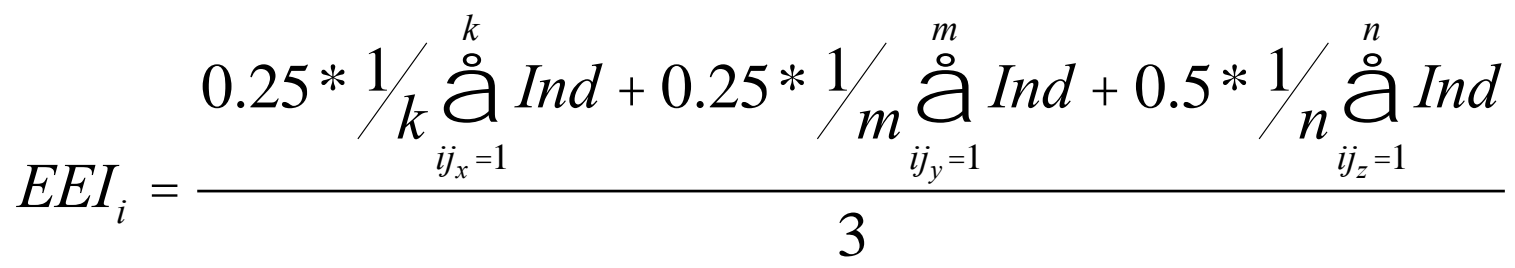

Where $i$ is the name of the country; Ind is the score of each indicator; $j$ is the set of 17 indicators; $j_{(x)}$ is the subset of indicators in the socio-economic environment; $j_{(y)}$ is the subset of indicators in the socio-cultural environment; $j_{(z)}$ is the subset of indicators in the governance environment; $k, m$ and $n$ are the overall number of indicators calculated for the socio-economic, socio-cultural and governance dimensions respectively.

Each indicator is calculated as follows:

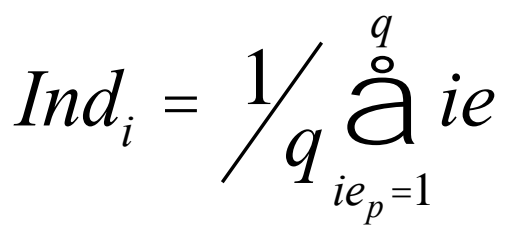

Where $i$ is the name of the country; $e$ is the standardized (or rescaled) value of the 53 data sources; $e_{p}$ is the subset of data sources available for a given indicator; $q$ is the amount of data sources available for a given indicator. 
In terms of standardization, we opted for a 0-1 scale, as it is a rather common feature in other types of capability-based social indicators. This means that some of the original data needed to be rescaled so as to achieve a standard format across the 53 data sources. Table 3 reports some examples of our rescaling methodology.

Table 3 - Examples of rescaling procedures for original data sources

\begin{tabular}{|c|c|c|}
\hline Original data source/indicator & Original scale & Rescaling procedure adopted \\
\hline Inequality adjusted HDI (2011) & 0,1 & No rescaling. \\
\hline $\begin{array}{l}\text { Seats in national parliament (\% } \\
\text { Female) -2011 }\end{array}$ & $0,100 \%$ & Divided by 100 . \\
\hline Gender Inequality Index 2011 & 0,1 & Rescaled as: (1-i) \\
\hline Government effectiveness (2010) & $-2.5,+2.5$ & $\begin{array}{l}\text { Rescaled as: }(i+2.5) / 5 \text {. As some scores } \\
\text { were lower than }-2.5 \text {, we decided to } \\
\text { convert them } 0 . \text { Those few scores score } \\
\text { higher than }+2.5 \text { were reassigned as } 1 \text {. }\end{array}$ \\
\hline Press Freedom Index (2012) & $-10,142$ & Rescaled as: $1-(\mathrm{i}+10) / 152$ \\
\hline Trade Unions Right Violations (2011) & 0,5080 & $\begin{array}{l}\text { Mean value was } 150 \text {. Thus, rescaled as: } 1- \\
\text { (i/150). All the scores higher than } 150 \text { (18 } \\
\text { scores) were scaled as } 0 \text {. }\end{array}$ \\
\hline
\end{tabular}

The decision to use more data sources for the calculation of the same indicators (53 data sources for 17 indicators) was based on the need to: 1) triangulate results whenever possible and avoid bias towards a specific source; 2) expand the coverage of countries, given that not all data sources covered the same number of countries. Through this approach, we managed to cover 224 countries and territories, virtually the entire world. Of course, here a caveat is in order. Although we were able to develop the full set of indicators for several countries, in most cases only a sub-set of indicators were available, thus affecting (albeit marginally) the reliability of the final EEI score. Due to the fact that the EEI in some countries and territories was based only on a sub-set of indicators, we established a data reliability cut-off at 14 indicators per country, that is, roughly $90 \%$ of the entire set of 
indicators. This gave us two lists of countries and territories. List A is made up of 109 countries and territories for which the EEI is based on 14 or more indicators. A list B, by contrast, includes all countries for which the EEI is based on less than 14 indicators. The full list of countries with their overall scores, as well as their complete dashboards, is available at: https://civicus.org/eei/

\section{A preliminary analysis of the data}

What does the EEI look like at the global level? This section zeros in on the overall results of the survey to show how a capability approach can produce new knowledge and (unexpected) findings, while offering a more nuanced assessment of civil society than conventional organizational surveys. In particular, the EEI demonstrates that affluent countries do not always exhibit a more enabling environment for civil society. In fact, when compared across the various dimensions, some rich societies fare worse than countries conventionally described as 'middle-income' or 'developing'. Some regions perform more poorly than expected, particularly in Asia, where the alleged economic miracle and socioeconomic gains of the last decades are not mirrored by the socio-cultural dimension and, most importantly, by the overall governance environment. Moreover, there is significant variance in terms of how most countries perform across the three dimensions, thus confirming the usefulness of a multidimensional approach that relies on a dashboard design.

Figure 2 reports the results of the EEI on a world map, in which darker shades of grey indicate a more enabling environment for civil society. 
Figure 2 - Global map of the EEI
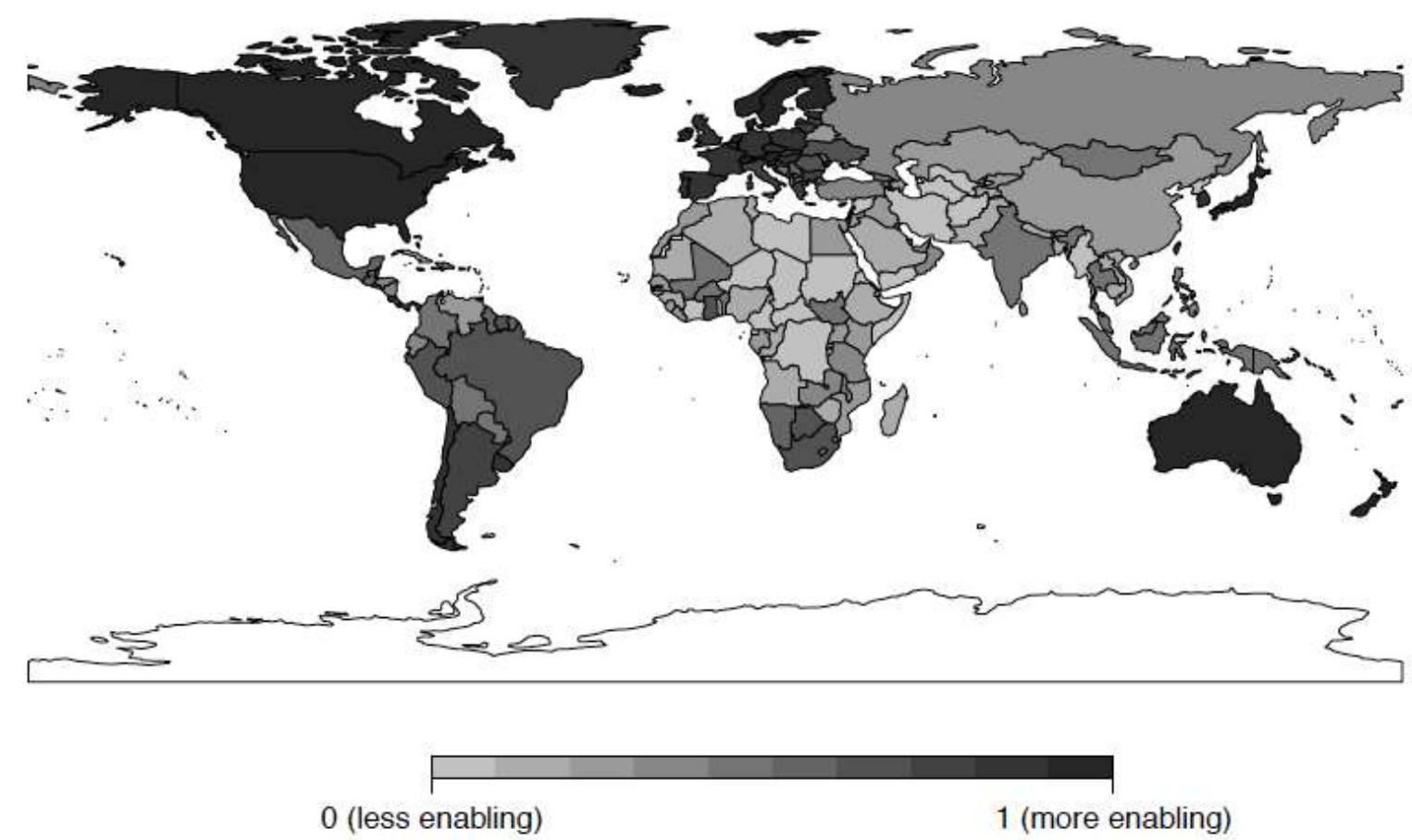

Table 4 reports the overall scores for the top and bottom 10 countries included in List A.

New Zealand is the only country consistently among the top five nations in all three dimensions (socio-cultural, socio-economic and governance), which makes it also the country with the world's highest aggregate EEI score (0.87). It is closely followed by Canada (0.85), another country with a strong governance apparatus, good communication infrastructure for civil society and robust human rights protections, but a relatively weaker socio-cultural environment. Australia (0.84) ranks third, followed by two Scandinavian countries, Denmark (0.81) and Norway (0.80). Interestingly, Sweden, a country traditionally considered among the top nations in terms of human development, is negatively affected in the assessment of civil society's enabling environment by a relatively 
Table 4 - Top 10 countries vs. bottom 10 countries as per List A (14 indicators or more)

\begin{tabular}{|l|c|l|c|c|}
\hline Top 10 countries & $\begin{array}{c}\text { EEI } \\
\text { score }\end{array}$ & $\begin{array}{l}\text { Socio-economic } \\
\text { environment }\end{array}$ & $\begin{array}{l}\text { Socio-cultural } \\
\text { environment }\end{array}$ & $\begin{array}{c}\text { Governance } \\
\text { environment }\end{array}$ \\
\hline New Zealand & 0.87 & 0.78 & 0.83 & 0.93 \\
\hline Canada & 0.85 & 0.77 & 0.78 & 0.93 \\
\hline Australia & 0.84 & 0.78 & 0.80 & 0.90 \\
\hline Denmark & 0.81 & 0.76 & 0.56 & 0.96 \\
\hline Norway & 0.80 & 0.83 & 0.53 & 0.91 \\
\hline Netherlands & 0.79 & 0.82 & 0.56 & 0.90 \\
\hline Switzerland & 0.79 & 0.76 & 0.54 & 0.94 \\
\hline Iceland & 0.79 & 0.78 & 0.54 & 0.94 \\
\hline Sweden & 0.79 & 0.82 & 0.51 & 0.92 \\
\hline United States of America & 0.79 & 0.73 & 0.78 & 0.72 \\
\hline Bottom 10 countries & EEI & Socio-economic & Socio-cultural & $\begin{array}{c}\text { Governance } \\
\text { environment }\end{array}$ \\
\hline Vietnam & 0.37 & 0.48 & 0.49 & 0.25 \\
\hline Angola & 0.37 & 0.49 & 0.33 & 0.42 \\
\hline Ethiopia & 0.36 & 0.34 & 0.58 & 0.25 \\
\hline Zimbabwe & 0.35 & 0.38 & 0.51 & 0.26 \\
\hline Guinea (Conakry) & 0.35 & 0.32 & 0.40 & 0.34 \\
\hline Gambia, The & 0.32 & 0.35 & 0.33 & 0.30 \\
\hline Burundi & 0.31 & 0.33 & 0.29 & 0.32 \\
\hline Iran & 0.31 & 0.42 & 0.49 & 0.17 \\
\hline Uzbekistan & 0.29 & 0.49 & 0.30 & 0.19 \\
\hline $\begin{array}{l}\text { Democratic } \\
\text { Republic of the Congo }\end{array}$ & 0.26 & 0.24 & 0.28 & 0.25 \\
\hline
\end{tabular}

low socio-cultural environment $(0.51)$, which is more modest than that of many countries in the so-called developing world, including Ethiopia, Benin and Botswana. In particular, a relatively low percentage of citizens in Sweden declare they would participate in a petition, march or boycott and the level of giving is also lower than in other countries, albeit not inconsistent with the Scandinavian average. While the United States is among the top in terms of socio-cultural factors, rather low scores in the socio-economic and governance environments negatively influence its overall EEI. Among the bottom five, we find a 
number of countries characterized by authoritarian rule, civil strife and lack of communication infrastructure. Ruled by an authoritarian regime with a poor human rights record, Uzbekistan (0.29) is considered to have the second worst enabling environment for civil society of all the countries included in the index. Burundi, which has emerged from a protracted civil war, is still wrangling with establishing the rule of law (0.31). While Vietnam receives a comparatively higher assessment for its socio-economic environment, it shows one of the lowest governance environments for civil society, mainly due to restrictions on individual participation outside of the government-controlled 'mass organizations'. Similarly, Ethiopia's civil society enjoys a partly favourable socio-cultural environment, which is however stifled by governance-related constraints on participation. Iran, among those at the very bottom (0.31), exhibits the world's worst governance track record for civil society (0.17). The list is closed by the Democratic Republic Congo, where socio-economic, socio-cultural and governance dimensions exhibit low to very low scores.

Other interesting findings include the fact that five of the countries ranked in the top ten in the socio-cultural dimension are in the Americas (Canada, United States of America, Colombia, Guatemala as well as Trinidad and Tobago). A high propensity to participate, a high degree of tolerance of different ethnic and religious groups and high public trust in civil society organizations are key attributes of these national contexts. With generally high education levels and good communications infrastructure, the continent that scores highest in the socio-economic dimension is Europe, with a regional average of 0.67, followed by the Asia Pacific (0.54), the Americas (0.51) and Africa (0.35). Over $90 \%$ of the European 
countries in the index have a higher score than the global average. The only sub-average countries in Europe are Macedonia, Montenegro, Georgia and Kosovo.

As we have already discussed, given its critical role in shaping the enabling environment for civil society, the governance dimension makes up half of the EEI score. Europe is the region with the highest score in the governance dimension, averaging 0.73 . Denmark is considered to have the most conducive governance environment for civil society, with a near perfect score of 0.96 . All other Nordic countries score particularly high on the governance dimension with Finland, Iceland, Norway and Sweden above 0.91 . Only $19 \%$ of countries in Europe were ranked below the global average of 0.58. All the European nations below the global average are post-communist countries, in which old authoritarian structures still wield significant influence and state policies often undermine genuine civic participation. Belarus (0.23) and Russia (0.34) are the two worst governance contexts for civil society in Europe. Belarus ranks $106^{\text {th }}$ out of the 109 countries included in List A.

The regional governance average for Africa is 0.44 , which is well below the global average for this dimension (0.58). The three most civil-society-friendly governance systems on the continent are found in the Southern Africa region. Botswana, South Africa and Namibia rank 39th, 40th and 41st out of 109 countries respectively. Botswana scores particularly high on guaranteeing freedoms of association (0.94) and South Africa has the most conducive environment for policy dialogue between civil society and the state (0.80). The West African nations of Ghana and Benin round off the top five best-governed countries in the continent, both countries scoring higher than 0.60 . Only $20 \%$ of countries in Africa 
surpass the global average of governance. Gambia, Zimbabwe, Democratic Republic of Congo and Ethiopia have the least favourable governance environments for civil society. This is due particularly to poor legal frameworks for civil society and severely strained relationships between civil society and the state.

The Asia-Pacific region has the lowest regional average for governance, which at 0.43 is even lower than the African average. After New Zealand and Australia, South Korea (0.72) and India (0.54) have the third and fourth best governance environments in the region. This sharp drop in scores indicates that there is a huge disparity in governance environments in the region. If New Zealand and Australia were not included in the region, the average score for Asia-Pacific would be 0.38. Developing economy powerhouses such as India (0.54), Indonesia (0.52) and Malaysia (0.44), are above the region's governance average, but they are well below the global average of 0.58 . The Asia-Pacific region has the highest number

of countries in the bottom ten (Tajikistan, Vietnam, Iran, Uzbekistan and China). Poor civil society-state relations, inadequate legal protections of civil and political rights and frequent violations of the freedoms of expression, association and assembly are the principal reasons that these countries have very low scores in the governance dimension.

\section{Conclusion: the relevance of a capability approach to civil society}

The application of the capability approach to the assessment of civil society around the world opens new opportunities for comparative research, while also reframing traditional frameworks of analysis. Providing a definition of civil society that encompasses the inherent diversity of forms and modes of civic participation around the world is virtually 
impossible. Even more cumbersome is to operationalize it for comparative quantitative assessments. In the end, such conceptual and methodological limitations call into question the usefulness of traditional exercises. From a scholarly point of view (as well as from a policy perspective), it is much more interesting to analyze the conditions that make people likely to participate in the civil society arena, regardless of the forms that such participation may take. As the Arab Spring has demonstrated, civil society participation can assume various characteristics, some of which defy traditional West-centric understandings of what civil society is. While previous approaches to civil society assessment were unable to anticipate the build-up of a civic resistance in the Arab world, and largely dismissed the entire region as unable to produce a strong civil society, a capability approach would have revealed the presence of more promising conditions, potentially leading to an upsurge of civil society action. For instance, the three countries spearheading the 2011 uprisings, that is, Tunisia, Egypt and Libya, show very low scores in terms of governance environment. However, their scores in the socio-economic and socio-cultural environments demonstrate significant potential for civic participation. Tunisia and Libya have a socio-economic dimension score of 0.44 and 0.49 respectively (higher than Turkey and India), while Egypt has a socio-cultural score of 0.51 (higher than some members of the European Union, such as the Czech Republic and Bulgaria).

Another advantage of the capability approach is that it defies general expectations as to which countries appear to fare better than others in aggregate terms. As we have already discussed, while Scandinavian countries are still among the best performing in the world, they are no longer at the top of the global ranking. Moreover, relatively poorer countries 
such as Uruguay (0.73) and Costa Rica (0.66) overtake traditional civil society 'good practices' such as Germany (0.70) and Italy (0.63) respectively. As discussed above, we adopted a reliability cut-off at 14 indicators, that is, just lower than a $90 \%$ threshold. This meant that many (smaller) countries and territories were excluded from the List A presented in this article. In the List B, there are some promising cases that command particular attention, such as Barbados (0.78), Hong Kong (0.73) and Taiwan (0.70). Further analysis will show whether these good performances are simply the result of limited data or real trends in the civil society's environment.

Another important advantage of the EEI approach is that it avoids unidimensional measurements of civil society. Although the final score provides an indication of the overall conditions of civil society's environment, the actual informational value is derived from the dashboard, which shows how different areas of civic participation may exhibit different trends. Some countries show deficits in the socio-economic dimensions, while others are affected by poor conditions in the socio-cultural fields. International aid agencies, policy makers and civil society activists will be much more interested in the specific scores of each dimension and indicator, rather than in the overall EEI score. To be actionable, the results of this research work must indeed be as context-specific as possible. Moreover, although the EEI gives primary importance to governance factors, the inclusion of other basic capabilities is equally important, as it helps us go beyond a legalistic understanding of civil society's operating environment. 
Needless to say, as the EEI is based on existing data, the quality of the exercise is dependent on the quality of each input. We have made a systematic effort at triangulating data sources whenever possible and at discarding indicators that had not direct bearing on the capability approach (such as nominal income). Yet, there is still a long way to go before we will be able to collect critical information about the key opportunity freedoms pertaining to collective action.

\section{Notes}

${ }^{a}$ The UN High Level Panel on the Post 2015 Development Agenda has explicitly requested the incorporation of civil society's enabling environment indicators in the future frameworks of international aid. More details available here: http://www.post2015hlp.org/the-report/ (accessed on 30 December 2013). In September 2013, US President Barack Obama made explicit reference to the importance of an enabling environment for civil society in his address to the UN General Assembly side event on civil society in September 2013. For more information, see:

http://www.whitehouse.gov/blog/2013/09/21/stand-civil-society-president-obama-hostforum-un-general-assembly (accessed on 30 December 2013).

${ }^{\mathrm{b}}$ In order to support the research process and strengthen its alignment with current trends in civil society, CIVICUS conducted various consultations with stakeholders throughout the world, whose results were then fed into the final methodology. More details about the consultations can be found here: http://civicus.org/downloads/2013EEI\%20REPORT.pdf (accessed on 30 December 2013). 


\section{References}

Abdelrahman, M. (2002) 'The Politics of “Un-civil” Society in Egypt,' Review of African Political Economy, 29 (91): 21-35.

Al-Sayyid, M.K. (1993) 'A Civil Society in Egypt?,' The Middle East Journal, 47 (2): 228242.

Allen, C. (1997) 'Who Needs Civil Society?', Review of African Political Economy, 24 (73): 329-337.

Calhoun, C. (2001) 'Civil Society/Public Sphere: History of the Concept,' in N.J. Smelser and P.B. Baltes (eds.) International Encyclopaedia of the Social and Behavioural Sciences (Amsterdam: Elsevier Science Ltd).

Carothers, T. (1999) ‘Civil Society: Think Again', Foreign Policy, Winter 1999-2000: 1829.

Carothers, T. and Ottaway, M. (eds.) (2000) Funding Virtue: Civil Society and Democracy Promotion (Washington, DC: Carnegie Endowment for International Peace).

Cohen, J. and Arato, A. (1994) Civil Society and Political Theory (Cambridge, MA: MIT Press).

Comim, F., Qizilbash, M. and Alkire, S. (eds) (2010) The Capability Approach: Concepts, Measures and Applications (Cambridge: Cambridge University Press).

Davies, J.C. (1962) ‘Toward a Theory of Revolution,' American Sociological Review, 27 (February): 5-18.

Diamond, L. (1994) ‘Toward Democratic Consolidation,' Journal of Democracy, 5 (3): 417. 
Edwards, M and Hulme, D. (eds) (1996) Beyond the Magic Bullet: NGO Performance and Accountability in the Post Cold War World (Bloomfield: Kumarian Press).

Edwards, M. (2009) Civil Society. $2^{\text {nd }}$ and Expanded Edition (Cambridge: Polity Press).

Ferguson, A. (1995) An Essay on the History of Civil Society (Cambridge and New York: Cambridge University Press).

Fioramonti, L. 'The Internal Contradictions of Global Civil Society: What Impact on Democracy?' Development Dialogue, 49 (2007): 131-141.

Fioramonti, L. (2013) Gross Domestic Problem: The Politics Behind the World's Most Powerful Number (London: Zed Books).

Fioramonti, L. and Fiori, A. (2010) 'Civil Society after Democracy: The Evolution of Civic Activism in South Africa and Korea,' Journal of Civil Society, 6 (1): 23-38.

Fowler, A. (2002) Civil Society Research Funding from a Global Perspective: a Case for Redressing Bias, Asymmetry and Bifurcation,' Voluntas: International Journal of Voluntary and Nonprofit Organisations, 13 (3): 286-300.

Gellner, E. (1996) Conditions of Liberty: Civil Society and Its Rivals (New York: Penguin Books).

Geschwender, J.A. (1968) 'Explorations in the Theory of Social Movements and Revolutions,' Social Forces, 47 (2): 127-135.

Gramsci, A. (1971) Selections from the Prison Notebooks of Antonio Gramsci (New York: International Publishers).

Grimond, J. (2001) 'Civil Society,' in D. Fishburn (ed.) The World in 2002 (London: The Economist Newspaper Limited).

Habermas, J. (1984) Theory of Communicative Action, Volume 2 (Boston: Beacon Press). 
Heinrich, V.F. (2005) 'Studying Civil Society Across the World: Exploring the Thorny Issues of Conceptualization and Measurement,' Journal of Civil Society, 1 (3): 211228.

Heinrich, V.F. and Fioramonti, L. (eds.) (2007) CIVICUS Global Survey of the State of Civil Society: Comparative Perspectives (Bloomfield: Kumarian Press).

Howard, M.J. (2003) The Weakness of Civil Society in Post-Communist Europe (Cambridge: Cambridge University Press).

Howard, M.J. (2005) 'Conceptual and Methodological Suggestions for Improving Crossnational Measures of Civil Society: Commentary on Heinrich,' Journal of Civil Society, 1 (3): 229-233.

Hunt, G. (1990) 'The Development of the Concept of Civil Society in Marx,' in B. Jessop and C. Malcolm-Brown (eds.) Karl Marx's Social and Political Thought: Critical Assessments (London and New York: Routledge).

Hyden, G., Court, J. and Mease, K. (2004) Making Sense of Governance: Empirical Evidence from 16 Developing Countries (Boulder: Lynne Rienner).

Jordan, L. and van Tujil, P. (2006) (eds) NGO Accountability. Politics, Principles and Innovations (London: Earthscan).

Keane, K. (1988) Civil Society and the State (London: Verso).

Kocka, J. (2006) 'Civil Society in Historical Perspective,' in J. Keane (ed.) Civil Society. Berlin Perspectives (New York and Oxford: Berghahn Books).

Lewis, D. (2001) 'Civil Society in non-Western contexts: Reflections on the 'usefulness' of a Concept,' Civil Society Working Paper Series 13. Centre for Civil Society, London School of Economics and Political Science, London. 
Lin, N. (2001) Social Capital. A Theory of Social Action and Structure (Cambridge: Cambridge University Press).

Locke, J. (1955) Two Treatises on Civil Government (London: J.M. Dent \& Sons)

Putnam, R.D. (2000) Bowling Alone: the Collapse and Revival of American Community (New York: Touchstone).

Roy, O. (2005) 'The Predicament of 'Civil Society' in Central Asia and the 'Greater Middle East,' International Affairs, 81(5): 1001-1012.

Salamon et al. (2004) (eds) Global Civil Society. Dimensions of the Nonprofit Sector (Bloomfield: Kumarian Press).

Salamon, L. and Anheier, H. (1998) 'Social Origins of Civil Society: Explaining the Nonprofit Sector Cross-nationally,' Voluntas: International Journal of Voluntary and Nonprofit Organisations, 9 (3): 213-248.

Scholte, J. A. (2000) 'Global Civil Society,' in N. Woods (ed.), The Political Economy of Globalization (London: Macmillan).

Seligman, A.B. (1992) The Idea of Civil Society (New York: Maxwell MacMillan International).

Sen, A. (1999) Development as Freedom (Oxford and New York: Oxford University Press).

Social Watch (2011) Basic Capabilities Index. Available online: http://www.socialwatch.org/taxonomy/term/523 (accessed on 30 December 2013).

Stiglitz, J.E., Sen, A. and Fitoussi, J.P. (2009) Report by the Commission on the Measurement of Economic Performance and Progress. The report is available online: www.stiglitz-se-fitoussi.fr (accessed on 30 December 2013). 
Tocqueville, A. de (2000) Democracy in America (Chicago: Chicago University Press).

UNDP (2013) Human Development Report 2013 (New York: UNDP).

USAID (2012) CSO Sustainability Index Report 2012 (Washington DC: USAID).

Van Rooy, A. (1998) Civil Society as Idea: An Analytical Hatstand?,' in A. Van Rooy

(Ed.) Civil Society and the Aid Industry: The Politics and Promise (London:

Earthscan).

Wood, E.M. (1990) ‘The Uses and Abuses of Civil Society,' Socialist Register 1990: The Retreat of the Intellectuals, 26: 60-84.

World Movement for Democracy and ICNL (2012) Defending Civil Society, $2^{\text {nd }}$ edition (Washington, DC: National Endowment for Democracy). 